\title{
Above and Below Ground Interactions in Monoculture and Intercropping of Onion and Lettuce in Greenhouse Conditions
}

\author{
Jessica L. de Haan, Liette Vasseur* \\ Department of Biological Sciences, Brock University, St. Catharines, Canada \\ Email: ${ }^{\text {Ivasseur@brocku.ca }}$
}

Received 4 August 2014; revised 19 September 2014; accepted 23 October 2014

Academic Editor: Vijayasankar Raman, University of Mississippi, USA

Copyright (C) 2014 by authors and Scientific Research Publishing Inc.

This work is licensed under the Creative Commons Attribution International License (CC BY). http://creativecommons.org/licenses/by/4.0/

(c) $\underset{\mathrm{EY}}{\mathrm{i}}$ Open Access

\begin{abstract}
Intercropping has been seen as an advantageous strategy in sustainable agriculture. Plants however interact with one another both above and below ground with members of the same species (intraspecific) or members of a different species (interspecific) for nutrients, water and light. It is therefore essential to understand these interactions when intercropped. The objective was to examine the above and below ground interactions between onion and lettuce in monocrop and intercrop systems. We examined the various possible interactions (no competition, above ground, below ground, or full) using a full factorial randomized design under greenhouse conditions. Onion yield was highest in intraspecific above ground competition and lowest in below ground and full interspecific competition with lettuce. Dry weight of onions in above ground competition with lettuce was significantly greater than that of the control group. Fresh weight of lettuce leaves were highest in below ground and full interspecific competition treatments. The hectare model and yield results suggest that there is strong below ground competitive effect between onion and lettuce in intercrop. Asymetric interspecific facilitation was found: facilitation by onion led to increased lettuce yield but a negative effect of lettuce on onion yield was observed. Knowledge of competitive interactions between component crops can have several applications in sustainable agricultural as it helps to match the most efficient species under specific conditions.
\end{abstract}

\section{Keywords}

Intraspecific and Interspecific Competition, Onion, Lettuce, Sustainable Agriculture, Facilitation

\footnotetext{
${ }^{*}$ Corresponding author.

How to cite this paper: de Haan, J.L. and Vasseur, L. (2014) Above and Below Ground Interactions in Monoculture and Intercropping of Onion and Lettuce in Greenhouse Conditions. American Journal of Plant Sciences, 5, 3319-3327.

http://dx.doi.org/10.4236/ajps.2014.521347
} 


\section{Introduction}

Intercropping is an agricultural technique based on the management of plant interactions to maximize crop yield and involves cultivating two or more crops in the same field within the same growing season [1] [2]. Intercropping can provide increased yields in an environmentally sustainable manner through resource complementarity, since niche overlap and competition between species is assumed to be reduced, permitting crops to capture a greater range and quantity of resources than in monoculture [3] [4].

Competitive interactions between two plants, brought about by a shared requirement for soil nutrients, water or light, can have negative effects on either species by decreasing growth rate, survival, reproduction or yield of one or both plants [5] [6]. In intercropping, the net effect of competition includes not only interspecific competition but also intraspecific competition [3]. In addition, competition can be above ground when plants modify their leaf areas in function of light interception, or below ground when plants alter the length, density, and spatial distribution of their roots in response to the presence of a neighbour [1] [6]. Lettuce (Lactuca sativa), for example, is expected to be more competitive in intercrop because it is a fast emerging, tall and broad-leaf plant that is able to obtain a larger share of available light than slower growing and smaller plants like onion [7]. Indeed, onion crops (Allium cepa) are known to be a weak competitor because of their initial slow growth rate after planting (juvenile growth), development of shallow fibrous roots and a small above ground canopy, which does not cover the soil [7].

In order to study competition in intercrop treatments and fully explore the yield potential of intercrops, we must examine and distinguish between the different types of interactions [3]. The cumulative and individual effects of above and below ground competition are not predictable; they vary with availability of resources and the species used [1]. Only by physically separating above ground competition from below ground competition can we distinguish between competition for light and competition for nutrients and water.

Research into cereal-legume intercrops is extensive and common in tropical and subtropical regions such as Africa and Asia. There is however limited research dedicated to vegetable or non-legume intercrops, intercrop competition and the specific interactions occurring between intercropped species, especially in temperate regions [2] [8] [9]. The objective of this experiment was to examine the interactions between onion and lettuce in monocultures and intercrops to determine whether the interactions were above or below ground, interspecific or intraspecific in nature, and if the interactions were positive (facilitative) or negative (competitive). It is hypothesized that the biomass for lettuce and onion intercrops will be greater than that of the monocultures. From this, we expect that intraspecific competition between lettuce plants will occur mainly above ground while interspecific competition between lettuce and onion will occur mainly below ground. Intraspecific competition between onions will be limited to minimal below ground interactions, while the biomass of onion plants in above ground competition with lettuce is expected to be negatively affected.

\section{Materials and Method}

\subsection{Experimental Design}

We used a complete random factorial design in a greenhouse setup where both intraspecific and interspecific competitions were examined using 11 treatments with 10 replicates: one single plant of onion 1) or lettuce 2) acted as the control groups; two plants of onion 3) or of lettuce 4) or one onion and one lettuce 5) planted in the same pot with full (above and below ground) interactions; two plants of onion 6) or of lettuce 7) or one onion and one lettuce 8) planted in a pot where the above ground portions were separated with greenhouse plastic (no above ground interaction); and two plants of onion 9) or of lettuce 10) or one onion and one lettuce 11) planted in two different pots but placed side by side (no below ground interaction). Seeds were sown directly into pots: onion at a depth of $2 \mathrm{~cm}$ and lettuce at a depth of $1 \mathrm{~cm}$ (according to the seed company). Seeds were spaced approximately $10 \mathrm{~cm}$ from each other in either the same pot for below ground and full competition, or in two pots for above ground competition treatments (one per pot) (note that the volume of soil was the same for all plants, whether in a larger pots for two plants or smaller pots for single plants). Plants were watered when the soil was dry to the touch. Fertilizer (20-20-20) was mixed into the water once every two weeks. Temperature varied between $15^{\circ} \mathrm{C}$ and $25^{\circ} \mathrm{C}$ with photoperiod of $14 \mathrm{~h}$ day/10 h night.

Lettuce was harvested after 55 days (on May 1, 2013). Fresh leaves were weighed and the samples were placed into a drying cabinet at $45^{\circ} \mathrm{C}$ for two weeks, at which point dry weight was recorded for each sample. The onion plants were left to grow for another 33 days and were harvested on June 3 - 4, 2013. Fresh bulb 
weight was immediately recorded, samples were placed in the drying cabinet, and after two weeks the dry onion samples were removed from the oven and weighed.

\subsection{Data Analyses}

Fresh and dry weight data were transformed using a natural logarithmic transformation to satisfy normality and compared between treatment groups with an analysis of variance followed by a multiple range Dunnett T3 posthoc test.

A model was created to estimate the yield of lettuce and onion in intercrop and monoculture in a simulated area of 1 hectare $(100 \mathrm{~m} \times 100 \mathrm{~m})$. The hectare model uses average yield from both the onion and lettuce, controls, intraspecific full competition and interspecific full competition treatments. In the onion monoculture model, rows were spaced $40 \mathrm{~cm}$ apart, and onion plants were spaced $10 \mathrm{~cm}$ apart within rows, in accordance with oniongrowing fact sheet [10]. In the lettuce monoculture model, lettuce rows were spaced $30 \mathrm{~cm}$ apart and plants were spaced $25 \mathrm{~cm}$ apart within rows. In the intercrop model, onion and lettuce were alternated every $12 \mathrm{~cm}$ with 30 $\mathrm{cm}$ between rows. Values were compared using a standard normal distribution (z-test).

The Relative Interaction Index (RII, [11]) was used to determine the types of interactions occur-ring between species in each treatment group. The fresh weight of onion bulbs and lettuce leaves were compared to their respective control groups using the following Equation (1):

$$
\mathrm{RII}=\frac{\mathrm{Mw}-\mathrm{Mo}}{\mathrm{Mw}+\mathrm{Mo}}
$$

where $\mathrm{Mw}$ is the fresh mass of plant matter (lettuce leaves or onion bulbs) in competition with neighbours, and Mo is the fresh mass of isolated plants (control). RII has values ranging from -1 to 1 , is symmetrical around zero and is negative for competition and positive for facilitation [11]. Given a 95\% confidence interval, a treatment was considered competitive if the RII value was less than -0.10 , facilitative if the RII value was greater than 0.10 , and neutral if the RII value was between -0.10 and 0.10 [11]. All statistical tests were performed using SPSS version 17.0.

\section{Results}

\subsection{Biomass and Yield Analyses-Onions}

Onion bulbs exposed to intraspecific above ground competition had the highest fresh weight. In interspecific competition, fresh bulb weight was the lowest in below ground and full competition with lettuce (Figure 1). Onions in interspecific below ground and full competition had significantly lower dry weight of bulbs than the onion control group, while onions growing in intraspecific above ground competition had the largest dry weight of bulbs (Figure 2). Additionally, onions in above ground competition with lettuce had significantly greater dry weight of bulbs than those in the control group.

When individual onions were grown in pots, i.e. with no competition, and extrapolated for yield in a field of 1 hectare, the results predicted the highest yield with a mean of $247 \mathrm{~kg} /$ ha (Figure 3). However, the mean value decreased to $185 \mathrm{~kg} / \mathrm{ha}$ (Figure 3) as soon as two onions grown in the same pot (simulating intraspecific monoculture) were considered. While this value considered the same spacing, it is clear that there is an interaction between individuals. The lowest yield is predicted when onions are planted in interspecific competition with lettuce (63 kg/ha, Figure 3). This value was statistically different than the monoculture yields $(\mathrm{p}<0.001)$.

\subsection{Biomass and Yield Analyses-Lettuce}

Lettuce yield was greatest in below ground and full interspecific competition with onion compared to intraspecific or no competition (Figure 4 and Figure 5). The hectare model for lettuce showed no significant difference between lettuce in individual pots (control) and in monocultures ( $p=0.464,6850 \mathrm{~kg} / \mathrm{ha}, 6893 \mathrm{~kg} / \mathrm{ha}$ ) (Figure 3). The yield of lettuce in interspecific competition with onion in the hectare model was both the highest lettuce yield observed, and statistically different than the yield of the monoculture models $(p=0.012,9821 \mathrm{~kg} / \mathrm{ha}$ ) (Figure 3).

\subsection{Competition vs Facilitation}

The effect of lettuce on onion was competitive in the below ground and full competition treatments, but was 


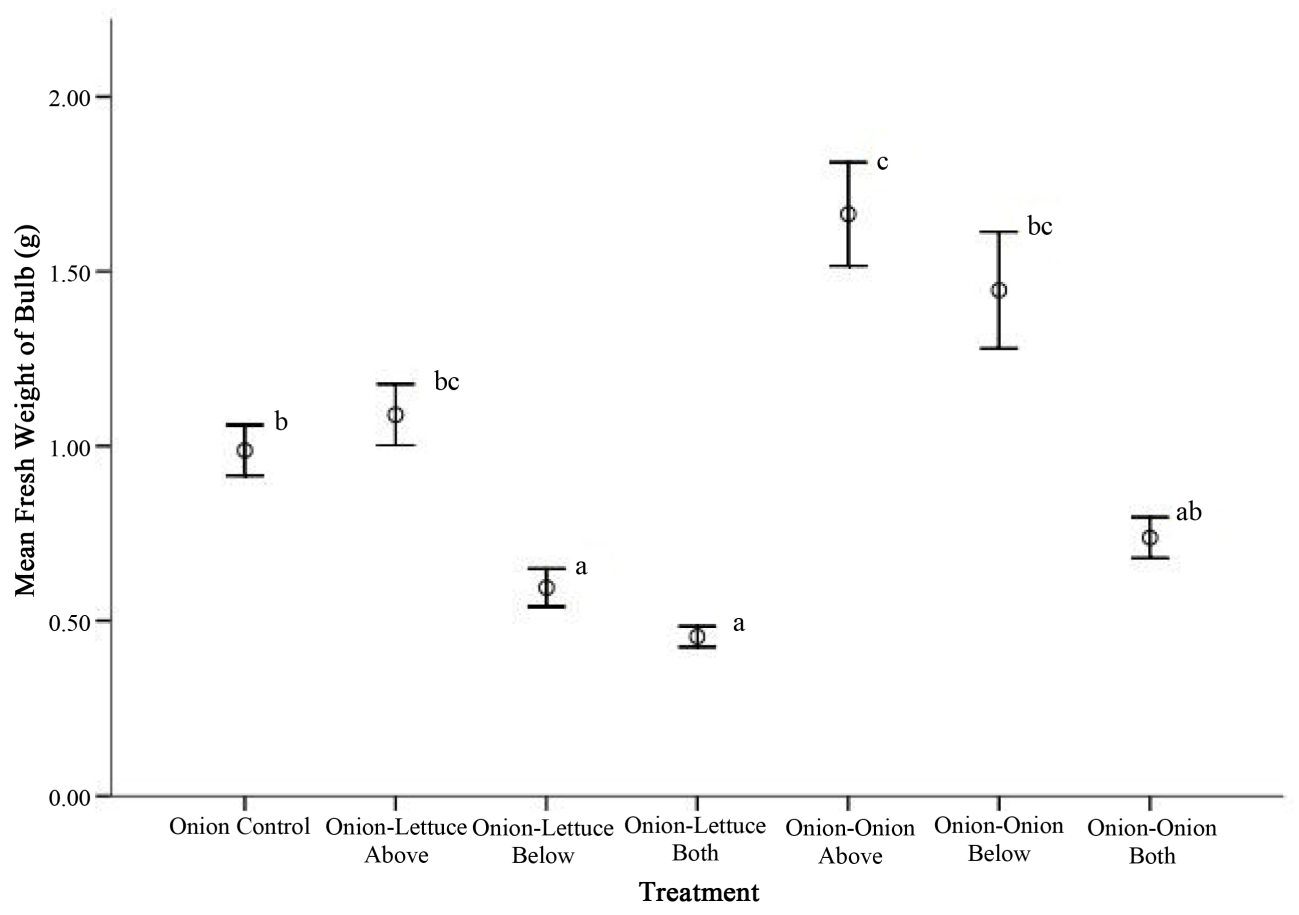

Figure 1. Average fresh weight of onion bulbs grown in control, intraspecific or interspecific competition with lettuce. An analysis of variance with a Dunnett T3 Post-hoc test was used to find significance between treatments. Letters next to the standard error bars note significance $\mathrm{df}=6, \mathrm{MS}=2.62, \mathrm{~F}=$ 17.04, $\mathrm{p}<0.001)$.

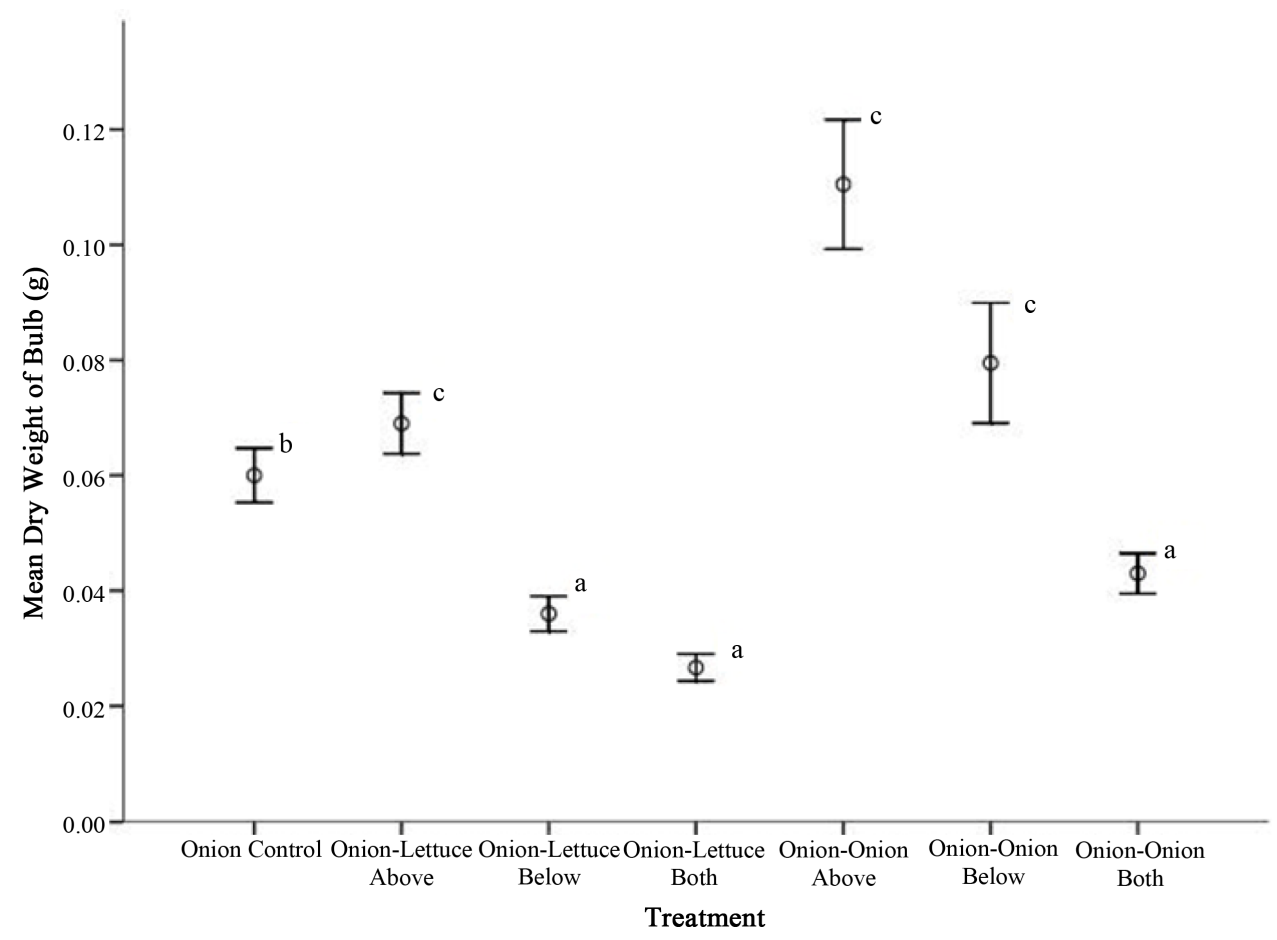

Figure 2. Comparison of average dry weight of onion bulbs grown in control, or competition with lettuce or onion. Significance between treatments is represented using letters next to the standard error bars, and was found using an analysis of variance with a Dunnett T3 Post-hoc test ( $\mathrm{df}=6, \mathrm{MS}=2.82$, $\mathrm{F}=13.94, \mathrm{p}<0.001)$. 


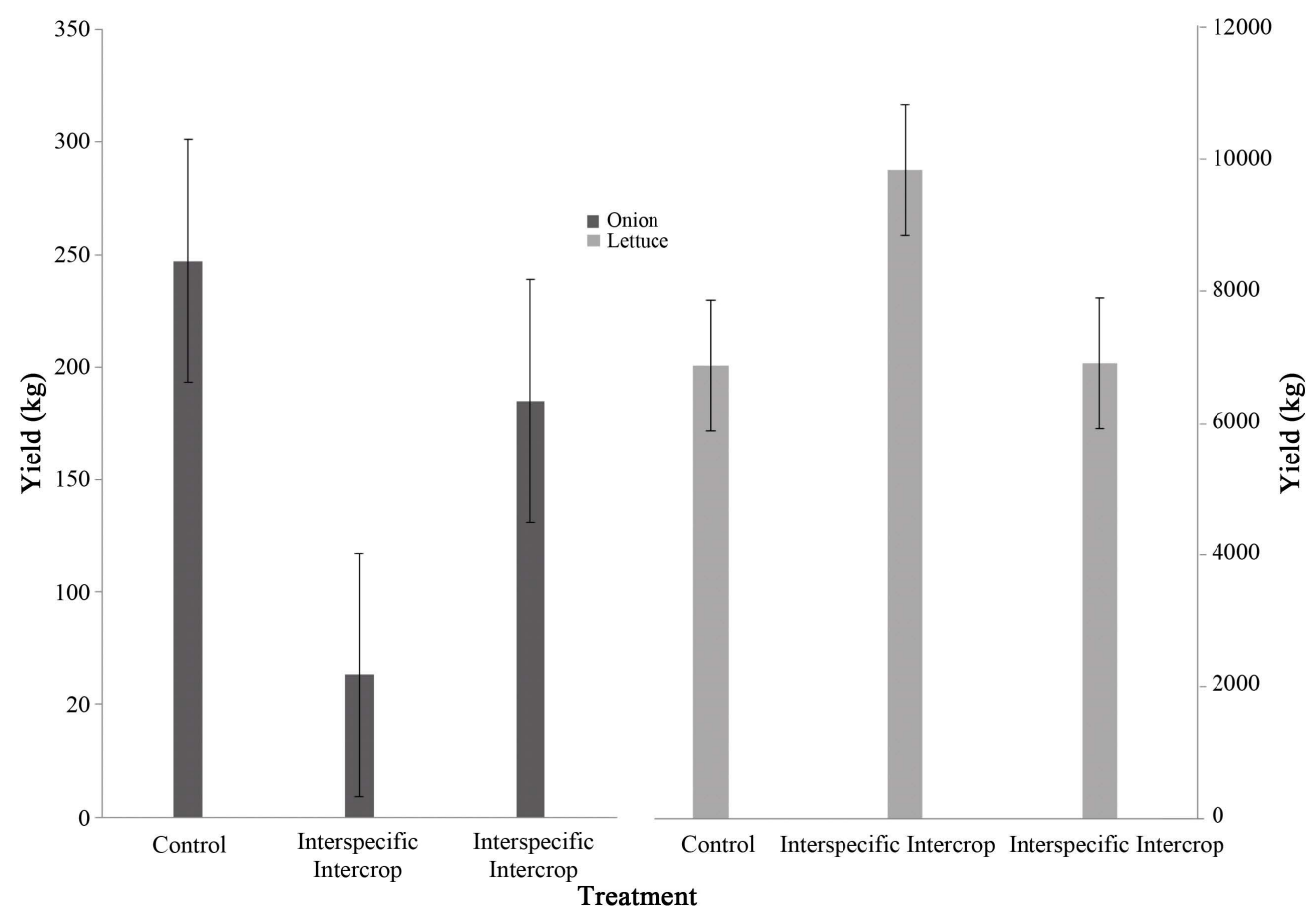

Figure 3. Predicted yield comparison of onion bulbs (kg/ha) for onion grown in monoculture assuming no competition, onion grown in monoculture with intraspecific competition and onions grown in an intercrop under interspecific competition with lettuce. Error bars are $+/-1$ standard error.

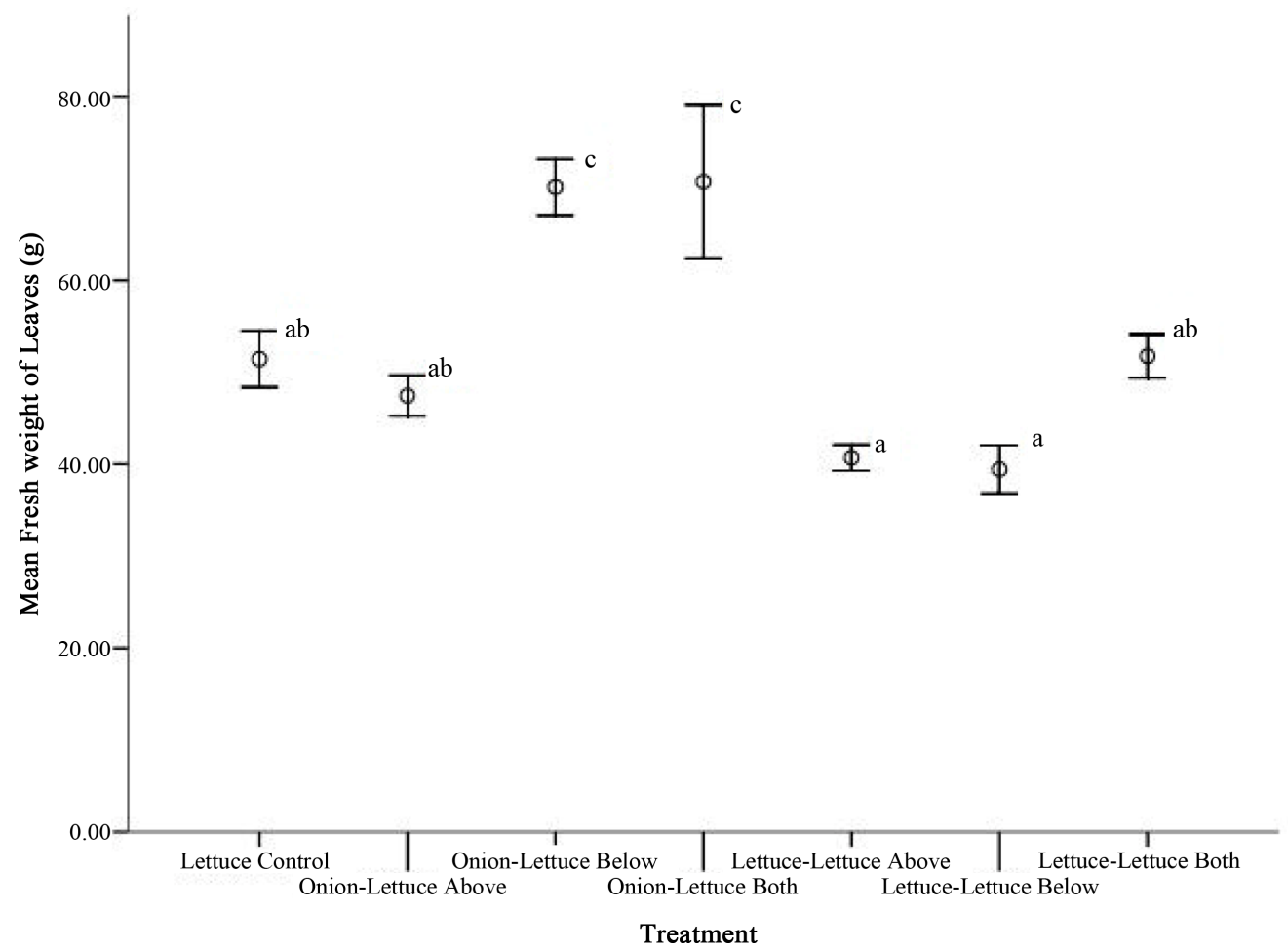

Figure 4. Comparison of average fresh weight of lettuce leaves growing in control and intraspecific and interspecific competition with onion. Significance was determined using analysis of variance with a Dunnett $\mathrm{T} 3$ post-hoc test, and is represented using letters adjacent to the standard error bars $(\mathrm{df}=6$, MS = $0.69, \mathrm{~F}=10.50, \mathrm{p}<0.001)$. 


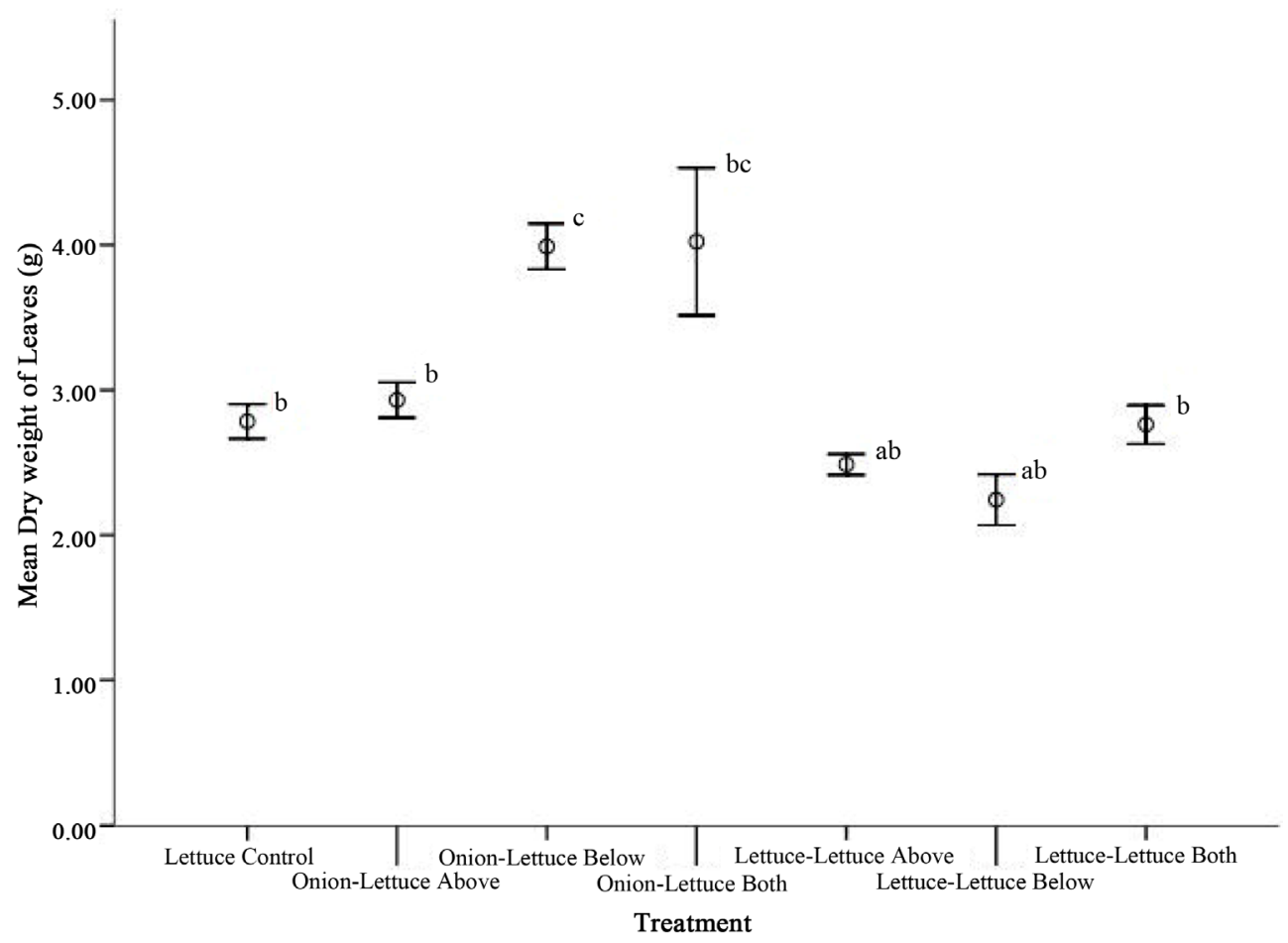

Figure 5. Average dry weight of lettuce leaves for lettuce grown in control, intraspecific or interspecific competition with onion. Letters beside error bars signify significance between treatments found using analysis of variance with a Dunnett T3 post-hoc test $(\mathrm{df}=6, \mathrm{MS}=0.63, \mathrm{~F}=8.67, \mathrm{p}<0.001)$.

neutral in the above ground competition treatment. Onion monoculture was facilitative in above ground interacttion as well as below ground interaction, but when paired in full competition, the effects were slightly competitive (Table 1(a)).

When lettuce was paired with onion above ground, there was a neutral effect, while a facilitative effect was observed when lettuce was paired with onion in below ground and full interaction treatments. The effects of lettuce in intraspecific interaction above ground and below ground were competitive, while there was a neutral effect for lettuce paired with lettuce in full interaction (Table 1(b)).

\section{Discussion}

Competitive interactions among plants of the same or different species can have either a positive or a negative effect on growth, reproduction, and survival [1] [5]. In this study, we hypothesized that the biomass for lettuce and onion intercrops would be greater than that of the monocultures. Indeed, for lettuce, we found that the biomass in intercrops with onion was generally greater than in monoculture. However, we also found that the yield of onion bulbs in all cases of intercrop with lettuce was equal to or lower than the biomass of monocultures. These results are especially visible in the predicted yield (hectare) model. It is known that onions are usually not very competitive against weeds or crops that are planted and growing at relatively the same time because of its slow growing habit [12]. Even once the lettuce removed, the recovery of onion in growth (measure in terms of plant height) was not significant (data not shown).

This unbalanced benefit of both crops in intercropping has been previously observed, showing the complexity of the system and its interactions [2]. Similar results were observed in a leek/celery inter-crop mixture where total yield was equal to the yield in the two species in monoculture, but celery competition reduced leek yield and quality [13]. In a cabbage/radish intercrop, yield of cabbage was significantly less in intercrop compared to monoculture [14]. This is known as asymmetric interspecific facilitation where the intercrop combination increases the yield of one species, but causes a decrease in the other [15].

The results suggested that the interactions were not necessarily similar for above and below ground. In interspecific competition, onions faired best in above ground interaction with lettuce. We expected that lettuce plants would shadow 
Table 1. Mean fresh weight of plant tissue (g), Relative Interaction Index (RII) values and type of interaction defined by RII for (a) onions when in intraspecific or interspecific competition with lettuce and (b) lettuce when in intraspecific or interspecific competition with onion.

(a)

\begin{tabular}{|c|c|c|c|}
\hline Treatment & Fresh Bulb Weight (g) & RII & Interaction \\
\hline Onion Control & 0.99 & & \\
\hline Onion-Onion Above & 1.66 & 0.25 & Facilitative \\
\hline Onion-Lettuce Above & 1.09 & 0.05 & Neutral \\
\hline Onion-Onion Below & 1.45 & 0.19 & Facilitative \\
\hline Onion-Lettuce Below & 0.59 & -0.25 & Competitive \\
\hline Onion-Onion Both & 0.74 & -0.14 & Slightly Competitive \\
\hline Onion-Lettuce Both & 0.45 & -0.38 & Competitive \\
\hline \multicolumn{4}{|c|}{ (b) } \\
\hline Treatment & Fresh Leaf Weight (g) & RII & Interaction \\
\hline Lettuce Control & 51.47 & & \\
\hline Lettuce-Lettuce Above & 40.68 & -0.12 & Facilitative \\
\hline Onion-Lettuce Above & 47.44 & -0.04 & Neutral \\
\hline Lettuce-Lettuce Below & 39.43 & -0.13 & Facilitative \\
\hline Lettuce-Onion Below & 70.13 & 0.15 & Competitive \\
\hline Lettuce-Lettuce Both & 51.75 & 0.00 & Slightly Competitive \\
\hline Lettuce-Onion Both & 70.71 & 0.16 & Competitive \\
\hline
\end{tabular}

onions, but it appears that below ground competition with lettuce limited onion growth more than above ground competition. The combined effect of full competition is therefore dominated by the below ground portion. A similar reduction of onion bulb yield due to intercropping with vegetables was noted by [16].

Our comparison between individual onion and onion in full or below ground competition also suggest that onions required greater spacing than what was stated by the seed company due to mainly below ground effect. Our results were similar to Peach et al. [17] who reported that intraspecific onion yield was improved by eliminating either above or below ground competition, but full competition greatly reduced yield. Aerts et al. [18] also found similar results.

It was expected that broader and more horizontal leaves of lettuce would lead to increased shading, as well as respiration and maintenance costs, thus likely reducing yield in intraspecific above ground competition [7] [19]. However, this was not necessarily the case; suggesting that light competition, at least at the soil surface, was not as much as a factor as expected [5].

Intercropping has been shown to have yield advantage presumably resulting from both above and below ground facilitation between intercropped species [15]. Contrary to our initial hypothesis, the RII of onion showed a facilitative effect in intraspecific above and below ground competition. In intercropping, onion played a neutral to facilitative role in the presence of lettuce. RII results for lettuce showed that in monoculture, neutral or slightly competitive effects would be found. The extensive root system of lettuce most likely exploited a large soil volume, contributing to its high interspecific competitive ability below ground, thus limiting soil moisture and nutrient availability for onions [20].

In the face of interactions or changes in environmental cues, plants can respond by emitting different biogenic volatile organic compounds or by modifying their internal hormonal balance [21]. Allelochemicals have been found to influence interactions between plants of different species thus reducing or improving their productivity potential [2]. While this aspect was not considered in this study, we can assume that some chemical interactions might have influenced plant responses and performance. The facilitative outcome observed in lettuce in interspecific below ground competition with onions may be due to the excretion of certain allelopathic chemicals such 
as growth promoting compounds [22] [23]. It may be interesting to consider these chemicals (most likely allelochemicals) in future studies.

Results from this study have promising applications in crop yield optimization and sustainable agriculture. While intercropping has been practiced in some countries for centuries, several questions remain unanswered regarding optimization of plant combinations, optimal density, spatial arrangements, or selective breeding necessary to produce maximum yields in full scale agricultural systems [2] [3]. Field testing, as mentioned in [2] will also be required to examine the influence of weeds and pests in such systems and determine whether allelochemicals from other species like weeds can affect the outcomes.

\section{Acknowledgements}

We thank V. De Luca for his involvement in the planning and execution of this study and the technical assistance of C. Carpenter-Cleland, A. Shidu, B. Amout. K. Dundas and A. Gheorghe. Funding to LV provided by Brock University.

\section{References}

[1] Mariotti, M., Masoni, A., Ercoli, L. and Arduini, I. (2009) Above and below Ground Competition between Barley, Wheat, Lupin and Vetch in a Cereal and Legume Intercropping System. Grass and Forage Science, 64, 401-412. http://dx.doi.org/10.1111/j.1365-2494.2009.00705.x

[2] Lithourgidis, A.S., Dordas, C.A., Damalas, C.A. and Vlachostergios, D.N. (2011) Annual Intercrops: An Alternative Pathway for Sustainable Agriculture. Australian Journal of Crop Science, 5, 396-410.

[3] Park, S.E., Benjamin, L.R. and Watkinson, A.R. (2002) Comparing Biological Productivity in Cropping Systems: A Competition Approach. Journal of Applied Ecology, 39, 416-426. http://dx.doi.org/10.1046/j.1365-2664.2002.00732.x

[4] Morsy, S.M., Drgham, E.A. and Mohamed, G.M. (2009) Effect of Garlic and Onion Extracts or Their Intercropping on Suppressing Damping-Off and Powdery Mildew Diseases and Growth Characteristics of Cucumber. Egyptian Journal of Phytopathology, 37, 35-46.

[5] Tilman, D. (1988) Plant Strategies and the Dynamics and Structure of Plant Communities. Princeton University Press, New Jersey.

[6] Jose, S., Williams, R. and Zamora, D. (2006) Below Ground Ecological Interactions in Mixed-Species Forest Plantations. Forest Ecology and Management, 233, 231-239. http://dx.doi.org/10.1016/j.foreco.2006.05.014

[7] Baumann, D.T., Bastiaans, L. and Kropff, M.J. (2001) Competition and Crop Performance in a Leek-Celery Intercropping System. Crop Science, 41, 764-774. http://dx.doi.org/10.2135/cropsci2001.413764x

[8] Andersen, M.K., Hauggaard-Nielsen, H., Ambus, P. and Jensen, E.S. (2004) Biomass Production, Symbiotic Nitrogen Fixation and Inorganic N Use in Dual and Tri-Component Annual Intercrops. Plant and Soil, 266, 273-287. http://dx.doi.org/10.1007/s11104-005-0997-1

[9] Andersen, M.K., Hauggaard-Nielsen, H., Weiner, J. and Jensen, E.S. (2007) Competitive Dynamics in Two- and ThreeComponent Intercrops. Journal of Applied Ecology, 44, 545-551. http://dx.doi.org/10.1111/j.1365-2664.2007.01289.x

[10] Jaime, M., Roberts, L. and McDonald, M.R. (2013) Growing Onion Transplants in Plug Trays. Ontario Ministry of Agriculture and Food. http://www.omafra.gov.on.ca/english/crops/facts/01-019.htm

[11] Armas, C., Ordiales, R. and Pugnaire, F.I. (2004) Measuring Plant Interactions: A New Comparative Index. Ecology, 85, 2682-2686. http://dx.doi.org/10.1890/03-0650

[12] Qasem, J.R. (2006) Response of Onion (Allium cepa L.) Plants to Fertilizers, Weed Competition Duration, and Planting Times in the Central Jordan Valley. Weed Biology and Management, 6, 212-220. http://dx.doi.org/10.1111/j.1445-6664.2006.00216.x

[13] Baumann, D.T., Bastiaans, L., Goudriaan, J., van Laar, H.H. and Kropfl, M.J. (2002) Analysing Crop Yield and Plant Quality in an Intercropping System Using an Eco-Physiological Model for Interplant Competition. Agricultural Systems, 73, 173-203. http://dx.doi.org/10.1016/S0308-521X(01)00084-1

[14] Guvenc, I. and Yildirim, E. (2006) Increased Productivity with Intercropping Systems in Cabbage Production. Journal of Sustainable Agriculture, 28, 29-44. http://dx.doi.org/10.1300/J064v28n04_04

[15] Li, L., Sun, J., Zhang, F., Guo, T., Bao, X., Smith, A.F. and Smith, S.E. (2006) Root Distribution and Interactions between Intercropped Species. Oecologia, 147, 280-290. http://dx.doi.org/10.1007/s00442-005-0256-4

[16] Narla, R.D., Muthomi, J.W., Gachu, S.M., Nderitu, J.H. and Olubayo, F.M. (2011) Effects of Intercropping Bulb Onion and Vegetables on Purple Blotch and Downy Mildew. Journal of Biological Sciences, 11, 52-27. 
http://dx.doi.org/10.3923/jbs.2011.52.57

[17] Peach, L., Benjamin, L.R. and Mead, A. (2000) Effects on the Growth of Carrots (Daucus carota L.), Cabbage (Brassica oleracea var. capitata L.) and Onion (Allium cepa L.) of Restricting the Ability of the Plants to Intercept Resources. Journal of Experimental Botany, 51, 605-615. http://dx.doi.org/10.1093/jexbot/51.344.605

[18] Aerts, R., Boot, R.G.A. and van der Aart, P.J.M. (1991) The Relation between Above- and Below Ground Biomass Allocation Patterns and Competitive Ability. Oecologia, 87, 551-559. http://dx.doi.org/10.1007/BF00320419

[19] Tei, F., Scaife, A. and Aikman, D.P. (1996) Growth of Lettuce, Onion, and Red Beet. 1. Growth Analysis, Light Interception, and Radiation Use Efficiency. Annals of Botany, 78, 633-643. http://dx.doi.org/10.1006/anbo.1996.0171

[20] Armas, C. and Pugnaire, F.I. (2011) Plant Neighbour Identity Matters to Below Ground Interactions under Controlled Conditions. PLoS One, 6, 1-7. http://dx.doi.org/10.1371/journal.pone.0027791

[21] Kegge, W. and Pierik, R. (2009) Biogenic Volatile Organic Compounds and Plant Competition. Trends in Plant Science, 15, 126-132. http://dx.doi.org/10.1016/j.tplants.2009.11.007

[22] Amin, A.A., Rahad, El-Sh.M. and El-Abagy, H.M.H. (2007) Physiological Effect of Indole-3-Butyric Acid on Growth, Yield and Chemical Constituents of Onion Plants. Journal of Applied Sciences Research, 3, 1554-1563.

[23] Shrestha, H. (2013) A Plant Monograph of Onion (Allium cepa). http://acepa.net76.net/Allium\%20cepa.pdf 
Scientific Research Publishing (SCIRP) is one of the largest Open Access journal publishers. It is currently publishing more than 200 open access, online, peer-reviewed journals covering a wide range of academic disciplines. SCIRP serves the worldwide academic communities and contributes to the progress and application of science with its publication.

Other selected journals from SCIRP are listed as below. Submit your manuscript to us via either submit@scirp.org or Online Submission Portal.
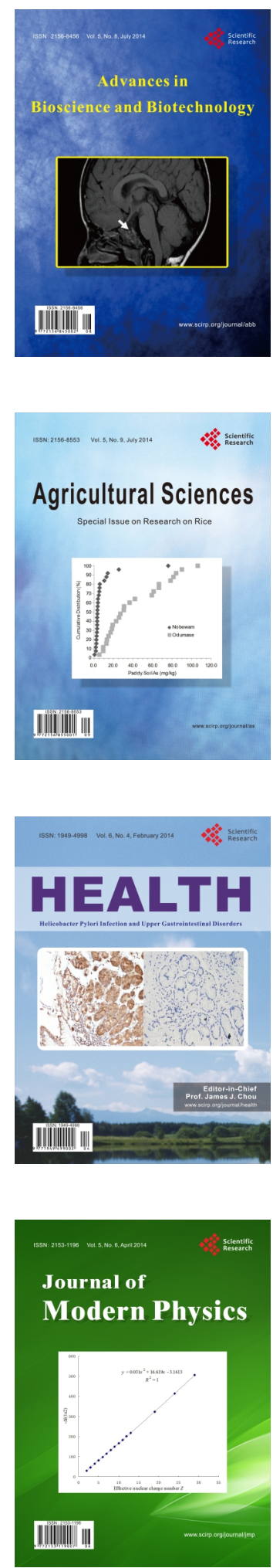
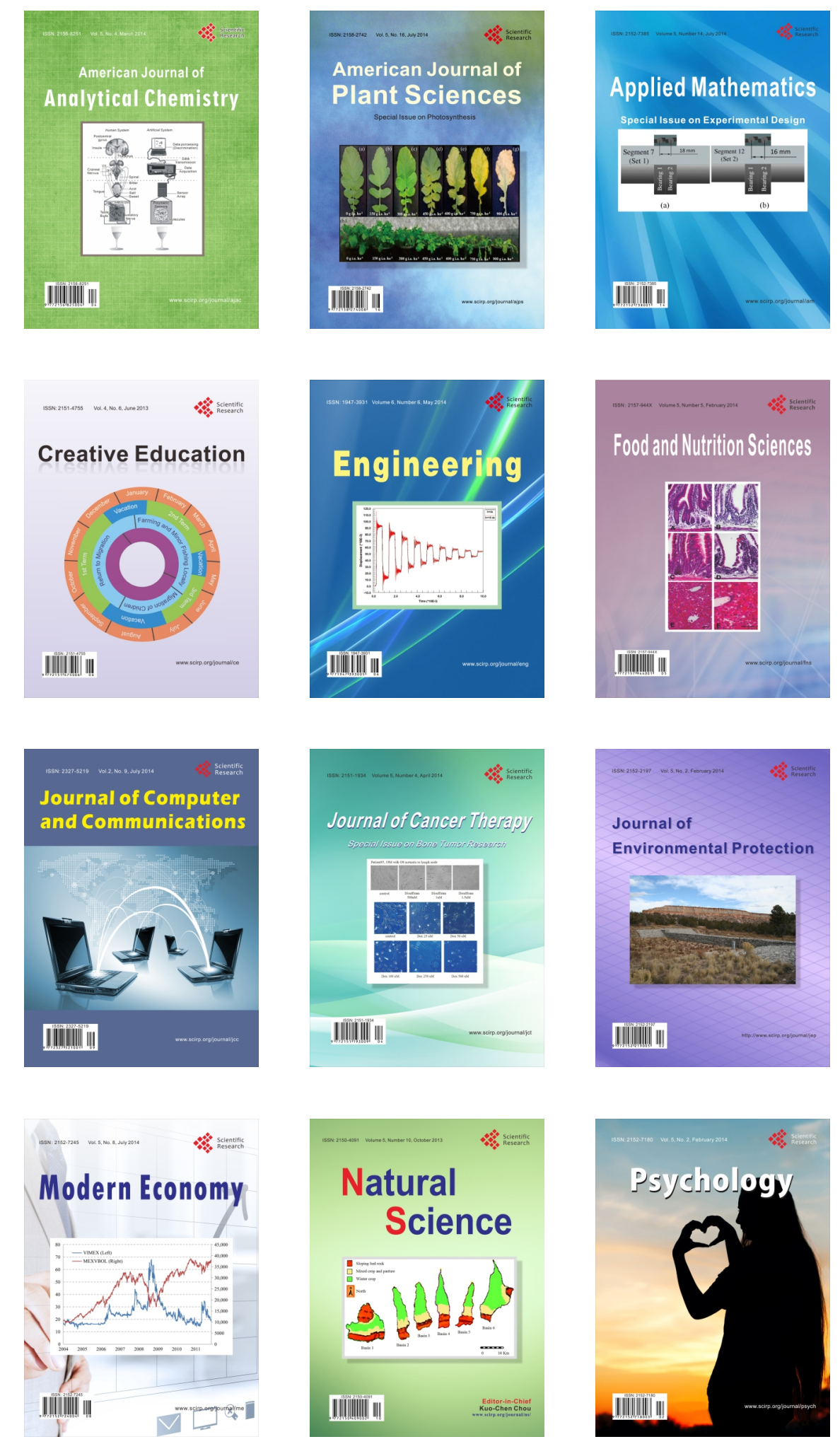